to the volumes on the "Fauna of British India". Series IV Part V. Journal of the Bombay Natural History Society 21: 411-446.

Hampson, G.F. (1912b). The moths of India. Supplementary paper to the volumes on the "Fauna of British India". Series IV Part VI. Journal of the Bombay Natural History Society 21: 878-911.

Hampson, G.F. (1912c). The moths of India. Supplementary paper to the volumes on the "Fauna of British India". Series IV Part VII. Journal of the Bombay Natural History Society 21: 1222-1272.

Hampson, G.F. (1912a). Descriptions of new species of pyralidae of the sub-family pyraustinae. Annals and Magazine of Natural History, London 9(8): 149-174.

Hampson, G.F. (1912b). Descriptions of new species of pyralidae of the sub-family pyraustinae. Annals and Magazine of Natural History, London 9(8): 242-269.

Hampson, G.F. (1912c). Descriptions of new species of pyralidae of the sub-family pyraustinae. Annals and Magazine of Natural History, London 9(8): 321-336.

Hampson, G.F. (1912d). Descriptions of new species of pyralidae of the sub-family pyraustinae. Annals and Magazine of Natural History, London 9(8): 433-444.

Hampson, G.F. (1912e). Descriptions of new species of pyralidae of the sub-family pyraustinae. Annals and Magazine of Natural History, London 9(8): 625-633.

Hampson, G.F. (1912f). Descriptions of new species of pyralidae of the sub-family pyraustinae. Annals and Magazine of Natural History, London 10(8): 1-20.

Hampson, G.F. (1912g). Descriptions of new species of pyralidae of the sub-family pyraustinae. Annals and Magazine of Natural History, London 9(8): 557-573.

Hampson, G.F. (1913a). Descriptions of new species of pyralidae of the sub-family pyraustinae. Annals and Magazine of Natural History, London 11(8): 322-342.

Hampson, G.F. (1913b). Descriptions of new species of pyralidae of the sub-family pyraustinae. Annals and Magazine of Natural History, London 9(8): 509-530.

Hampson, G.F. (1913c). Descriptions of new species of pyralidae of the sub-family pyraustinae. Annals and Magazine of Natural History, London 12(8): 1-38.

Hampson, G.F. (1917). Descriptions of new species of pyralidae of the sub-family pyraustinae. Annals and Magazine of Natural History, London 20(8): 369-384.

Hampson, G.F. (1918a). Descriptions of the sub-family pyraustinae. Annals and Magazine of Natural History, London 21: 125-136.

Hampson, G.F. (1918b). Descriptions of the sub-family pyraustinae. Annals and Magazine of Natural History, London 21: 252-262.

Hampson, G.F. (1918c). Descriptions of the sub-family pyraustinae. Annals and Magazine of Natural History, London 21: 265-280.

Hampson, G.F. (1918d). Descriptions of the sub-family pyraustinae. Annals and Magazine of Natural History, London 22: 181-196.

Hampson, G.F. (1918e). Descriptions of the sub-family pyraustinae. Annals and Magazine of Natural History, London 22: 393-407.

Kirti, J.S. \& H.S. Rose (1989). First record of genus Toxobotys Munroe \& Mutuura (Pyraustinae: Pyralidae: Lepidoptera) from Oriental Region. Journal of Insect Science 2(1): 10-13.

\section{NEW LARVAL FOOD PLANTS OF EUPLOEA CORE CORE (CRAMER) (NYMPHALIDAE: LEPIDOPTERA: INSECTA)}

\author{
Muhamed Jafer Palot and C. Radhakrishnan \\ Zoological Survey of India, Western Ghats Field Research Station \\ Annie Hall Road, Kozhikode, Kerala 673002, India.
}

The Common Crow, Euploea core core (Cramer) is a widespread butterfly occurring in many habitats. It is a polyphagous insect, known to feed on a variety of plant species including Ficus bengalensis, F. racemosa, F. religiose, F. elastica, Streblus asper (Moraceae); Cryptolepis elegans, C. buchanani, Hemidesmus indicus, Tylophora indica (Asclepiadaceae); Holarrhena pubescens, Ichnocarpus frutescens, Nerium odorum and N. oleander (Apocynaceae) as reported by Wynter-Blyth (1957), Gay et aL (1992) and Kunte (2000).

Since 1993, we have been observing Common Crows laying eggs on the young reddish buds of Ficus arnottiana (Moraceae), a common fig tree found along the rocky parts of the Madayipara hills, Payangadi, Kannur District, Kerala. We have also observed its breeding on Carissa carindas (Apocynaceae), a small spiny climbing shrub cultivated in the area. All records were during monsoon from June to August and many golden pupae were noted during this period.

\section{Acknowledgments}

We thank Dr. J.R.B. Alfred, Director, Zoological Survey of India, Calcutta for encouragement and work facilities; Dr A.K. Pradeep, Curator, Department of Botany, University of Calicut for confirmation of the plant species.

\section{References}

Gay, T., I.D. Kehimkar and J.D. Punetha (1992). Common Butterflies of India. World Wide Fund for Nature- India, Bombay, 67pp.

Kunte, K. (2000). Butterflies of peninsular India. University Press (India) Limited, Hyderabad, 254pp.

Wynter-Blyth, M.A. (1957). Butterflies of the Indian Region. Bombay Natural History Society, Bombay, 523pp.

Received 3 July 2001;

Accepted 3 August 2001 